\title{
PENGARUH PARTISIPASI ANGGARAN, TEKNOLOGI INFORMASI, GAYA KEPEMIMPINAN, DAN KEPUASAN KERJA TERHADAP PRODUKTIVITAS KERJA KARYAWAN
}

\author{
I Made Adwityam Dewantara', Putu Ekadianita Marvilianti Dewi², \\ Anantawikrama Tungga Atmadja ${ }^{3}$
}

\author{
Jurusan Ekonomi dan Akuntansi, Fakultas Ekonomi, Universitas Pendidikan Ganesha \\ Singaraja, Indonesia
}

e-mail: madeadwityamdewantara@gmail.com, ekadianita@undiksha.ac.id

anantawikramatunggaatmadja@undiksha.ac.id

\begin{abstract}
Abstrak
Penelitian ini bertujuan untuk mengetahui pengaruh partisipasi anggaran, teknologi informasi, gaya kepemimpinan, dan kepuasan kerja terhadap produktivitas kerja karyawan. Penelitian ini menggunakan pendekatan kuantitatif yang menggunakan instrumen dalam pengukurannya dan mengolahnya secara statistik. Penelitian ini dilakukan pada CV Tenaga Inti Sangsit dan CV. Bima Sakti. Populasi dalam penelitian ini adalah seluruh karyawan pada CV Tenaga Inti Sangsit dan CV. Bima Sakti sejumlah 80 orang. Metode pengambilan sampel yang digunakan dalam penelitian ini adalah metode sampel jenuh/total sampling, sehingga jumlah sampel sama dengan populasi yakni 80 responden. Data penelitian ini dikumpulkan dengan menggunakan kuesioner yang kemudian diolah dengan analisis regresi linear berganda menggunakan bantuan SPSS.

Hasil penelitian menyatakan bahwa partisipasi anggaran, teknologi informasi, gaya kepemimpinan, dan kepuasan kerja secara individual masing-masing berpengaruh positif dan signifikan terhadap produktivitas kerja karyawan pada CV Tenaga Inti Sangsit dan CV. Bima Sakti. Penelitian ini berimplikasi bahwa diperlukan adanya partisipasi pimpinan dalam penyusunan anggaran dan hendak diterapkan kepemimpinan yang partisipasif. Selain itu, perusahaan hendak menerapkan teknologi informasi dan karyawan diharapkan dapat meningkatkan kepuasan kerja.
\end{abstract}

Kata kunci: produktivitas, partisipasi anggaran, teknologi informasi, gaya kepemimpinan, kepuasan kerja

Abstract

This study aims to determine the effect of budgetary participation, information technology, leadership style, and job satisfaction on employee work productivity. This study uses a quantitative approach that uses instruments in their measurements and processes them statistically. This research was carried out on CV. Tenaga Inti Sangsit and CV. Bima Sakti. The population in this study were all employees at the CV Tenaga Inti Sangsit and CV. Bima Sakti numbered 80 people. The sampling method used in this study is the saturated / total sampling method, so that the number of samples is the same as the population of 80 respondents. The data of this study were collected using a questionnaire which was then processed by multiple linear regression analysis using SPSS.

The results of the study stated that budgetary participation, information technology, leadership style, and individual job satisfaction had a positive and significant effect on employee work productivity on the CV Tenaga Inti Sangsit and CV. Bima Sakti. This research implies that leadership participation is needed in budgeting and participatory leadership is to be implemented. In addition, companies want to apply information technology and employees are expected to increase job satisfaction.

Keywords: productivity, budget participation, information technology, leadership style, job satisfaction 


\section{Pendahuluan}

Perkembangan bisnis dan persaingan antar perusahaan pada masa sekarang ini semakin ketat. Hal tersebut akan berdampak pada pelanggan, persaingan usaha dan perubahan. Dalam kondisi persaingan usaha dibidang jasa akan menyebabkan suatu ketidakpastian dalam lingkungan bisnis yang akan menimbulkan kesulitan dalam proses perencanaan dan pengendalian manajemen perusahaan. Semua ini menuntut manajemen perusahaan untuk merencanakan masa depan perusahaan dengan sungguh-sungguh, sehingga perusahaan dapat bertahan dan bersaing dalam kompetisi yang kuat. Kemajuan dari perusahaan sangat bergantung pada pengelolaan manajer yang ada dalam perusahaan, agar manajer dapat menjalankan fungsinya sesuai dengan tujuan dan sasaran yang hendak dicapai dan kemudian membuat rencana kegiatan untuk mencapai tujuan dan sasaran tersebut.

Seperti halnya pada industri lain, pasar jasa konstruksi di Indonesia sangat dipengaruhi oleh daya beli dari masyarakat dan pemerintah, dimana daya beli ini berkaitan erat dengan perkembangan ekonomi makro Indonesia yang mengalami gangguan akibat krisis ekonomi yang terjadi pada tahun 1997/1998 tersebut. Sebelum krisis ekonomi pada tahun 1997, Biro Pusat Statistik (BPS, 2006a) mencatat adanya pertumbuhan di sektor konstruksi yang mencapai $13,71 \%$ per tahun. Tingkat pertumbuhan ini lebih tinggi dari pertumbuhan ekonomi nasional yang mencapai 7,85\%. Akan tetapi setelah krisis ekonomi menyerang Indonesia, konstruksi merupakan sektor yang paling merasakan imbas dari krisis ekonomi tersebut dimana sektor konstruksi pada tahun 1998 terpuruk hingga minus 36,4\% dan mengalami pertumbuhan yang paling parah dibandingkan sektor ekonomi yang lainnya seperti manufaktur dan pertanian.

Dalam kurun waktu tersebut, perusahaan-perusahaan jasa konstruksi sangat terpukul pada saat terjadinya krisis ekonomi karena volume pekerjaan konstruksi berkurang drastis, proyek ditangguhkan atau dihentikan sementara oleh pemiliknya dan juga pemilik proyek banyak yang kesulitan melakukan pembayaran kepada kontraktor. Sementara dalam waktu yang bersamaan, kontraktor memiliki kewajiban membayar kepada pihak ketiga, terutama pengusaha golongan ekonomi lemah, disamping harus membayar bunga pinjaman kepada pihak perbankan dimana pada saat itu suku bunga perbankan melonjak drastis sampai mencapai sekitar 25-26\% per tahunnya. Untuk dapat mencegah hal tersebut, suatu perusahaan dalam melaksanakan kegiatannya, akan berusaha untuk mencapai tujuan yang telah ditetapkan sebelumnya. Satu hal yang penting yaitu bahwa, keberhasilan berbagai aktivitas didalam perusahaan dalam mencapai tujuan bukan hanya tergantung pada keunggulan teknologi, dana operasi yang tersedia, sarana dan prasarana yang dimiliki, melainkan juga tergantung pada aspek sumber daya manusia. Sumber daya manusia yang dimaksud adalah orang-orang yang memberikan tenaga, pikiran, bakat, kreativitas dan usahanya pada perusahaan.

Setiap perusahaan berupaya untuk mendapatkan karyawan yang pernah terlibat dalam kegiatan organisasi atau perusahaan, sehingga dapat memberikan kontribusi pada pencapaian target yang telah ditetapkan perusahaan. Target yang dicapai karyawan merupakan produktivitas kerja yang dapat diukur secara kualitas maupun kuantitas yang dicapai persatuan periode waktu dalam melaksanakan tugas kerja sesuai dengan tanggung jawab yang diberikan. Setiap organisasi atau perusahaan dalam melaksanakan program selalu diarahkan untuk mencapai efisiensi dan efektivitas untuk mencapai tujuan perusahaan. Salah satu caranya adalah dengan meningkatkan produktivitas kerja karyawan. Memiliki produktivitas kinerja karyawan yang baik untuk menciptakan prestasi kerja, bukan hanya untuk kerjasama antar perusahaan tetapi kekompakan dalam membangun kerjasama antara menejer dan karyawannya. Karena itu, manajemen perusahaan harus bekerja secara efektif dan efesien untuk mencapai hal tersebut.

Produktivitas kerja karyawan pada sebuah perusahaan merupakan masalah yang selalu hangat dan tidak ada habis-habisnya untuk dibahas. Permasalahan yang terkait dalam produktivitas juga merupakan isu strategis bagi perusahaan yang memprogram masalah sumber daya manusia. Banyak aspek intenal dan eksternal yang mendukung terciptanya produktivitas kerja yang efektif dan efisien dalam suatu perusahaan. Apalagi bila 
dikaitkan dengan masalah globalisasi yang melanda saat ini yang dampaknya sangat kita rasakan.

Salah satu indikator yang mempengaruhi dalam upaya meningkatkan produktivitas yang efektif dan efisien adalah gaya kepemimpinan dan human relation yang diterapkan oleh pimpinan perusahaan. Produktivitas merupakan sikap mental yang mempunyai pandangan bahwa untuk kehidupan hari ini akan lebih baik dari hari kemarin dan hari esok adalah lebih baik dari hari ini. Secara umum produktivitas adalah perbandingan atau rasio antara output dan input. Penggunaan rasio ini harus memperhatikan aspek karyawan (kualitas dan jumlah), aspek kepemimpinan (pengarahan dan pembinaan) maupun aspek sasaran kerja yang harus dicapai disamping kapasitas mesin pengelolanya (teknologi). Karena faktor manusia merupakan faktor produktivitas yang terpenting, maka dalam pengelolaannya pun harus berbeda dari faktor produksi yang lain. Para karyawan itu adalah manusia yang mempunyai pribadi yang beraneka ragam yang harus dihormati dan dihargai harkat dan martabatnya.

Peneliti meneliti bidang jasa kontruksi karena di era pemerintahan saat ini pemerintah mengembangkan infrastruktur berbasis modern yang pelaksanaanya di Indonesia sangat baik guna menunjang perekonomian negara. Oleh karena itu, jasa kontruksi sangat berpengaruh besar bagi pembangunan di Indonesia, dan menuntut perusahaan jasa kontruksi untuk berkembang lebih baik lagi dengan mengikuti perkembangan di era modern ini diharapkan perusahaan konstruksi mampu untuk bekerja secara produktif. Akan tetapi, yang terjadi di lapangan khususnya pada perusahaan CV. Tenaga inti dan CV. Bima Sakti dengan masalah yang sama di alami kedua perusahaan tersebut masih terdapat permasalahan dalam partisipasi anggran, teknologi informasi, gaya kepemimpinan, dan kepuasan kerja.

Partisipasi dalam penyusunan anggaran merupakan faktor kritis yang dapat mempengaruhi keefektifan pencapaian tujuan organisasi secara keseluruhan. Efek-efek yang ditimbulkan oleh partisipasi secara umum adalah positif dengan mengacu pada moral, motivasi, inisiatif, kinerja, prestasi kerja, kepuasan kerja, serta sikap bawahan terhadap pekerjaan, supervisor, dan organisasi itu sendiri. Hal ini didasarkan pada kenyataan bahwa anggaran diartikan sebagai rencana kegiatan yang mencakup berbagai kegiatan operasional yang saling berkaitan dan saling mempengaruhi satu sama lain dalam orgaisasi. Perusahaan membutuhkan anggaran sebagai salah satu komponen penting agar tetap bertahan dalam lingkungan bisnis yang cepat berubah seperti sekarang ini.

Sebuah organisasi membutuhkan anggaran untuk menerjemahkan seluruh strategi menjadi rencana dan tujuan jangka pendek dan jangka panjang (Hansen dan Mowen, 2009:356). Proses penyusunan anggaran merupakan kegiatan yang penting dan melibatkan beberapa pihak baik manajer tingkat atas maupun manajer tingkat bawah. Menurut Faizzah dan Mildawati (2007:352) anggaran merupakan peralatan pengawasan yang sangat meluas baik dalam dunia bisnis maupun pemerintahan. Penyiapan anggaran adalah suatu bagian integral dari proses perencanaan, anggaran itu sendiri adalah hasil akhir dari proses perencanaan, atau perencanaan rencana. Berdasarkan uraian di atas, maka hipotesis pertama yang diajukan adalah sebagai berikut:

$\mathrm{H}_{1}$ : Partisipasi anggaran berpengaruh positif dan signifikan terhadap produktivitas kerja karyawan pada CV. Tenaga Inti dan CV. Bima Sakti.

Perkembangan ekonomi Indonesia juga seiring dengan perkembangan teknologi informasi, termasuk juga untuk industri jasa konstruksi. Hampir semua bidang kehidupan dan industri sudah tersentuh oleh teknologi informasi baik itu entertainment, kesehatan, pendidikan, asuransi, bank dan bahkan untuk pemerintahan pun teknologi informasi sudah banyak digunakan. Teknologi informasi dalam suatu perusahaan sudah menjadi hal yang sangat penting dan sudah menjadi kebutuhan dasar bagi setiap perusahaan, terutama dalam menjalankan aktivitasnya mulai dari proses produksi sampai dengan pemasaran membutuhkan teknologi informasi. Dengan penerapan teknologi secara tepat, suatu perusahaan dapat memiliki competitive advantage dalam industrinya. Karena, dengan teknologi informasi membuka kemungkinan perusahaan untuk mengembangkan dan memperluas bisnisnya. 
Dalam persaingan, teknologi informasi tampaknya bukan hanya menjadi suatu alat pendukung tetapi sudah merupakan alat utama. Laksamana dan Muslichah (2002: 106-125) menyatakan bahwa teknologi informasi meningkatkan peningkatan penyampaian informasi kepada konsumen dan memudahkan pengumpulan informasi tentang data konsumen dan pasar. Kegunaan teknologi informasi yang canggih berbasis komputer memungkinkan manajemen untuk menerapkan sistem informasi manajemen (SIM) yang dapat memberikan informasi-informasi yang diorientasikan untuk membantu pembuatan keputusan oleh manajer dan melakukan inovasi yang seluas-luasnya dalam upaya menciptakan berbagai strategi pembangunan keunggulan daya saing perusahaan sehingga perusahaan akan mampu mengelola sumber daya secara penuh, efektif, dan efisien. Berdasarkan uraian di atas, maka hipotesis kedua yang diajukan adalah sebagai berikut:

$\mathrm{H}_{2}$ : Teknologi informasi berpengaruh positif dan signifikan terhadap produktivitas kerja karyawan pada CV. Tenaga Inti dan CV. Bima Sakti.

Dalam suatu organisasi tentunya perlu adanya hirarki pimpinan dan bawahan. Oleh karena itu perlu adanya sumber daya manusia yang berkualitas untuk menjadi pimpinan dan bawahan. Sudarsono (2006) mengungkapkan bahwa sumberdaya manusia adalah tenaga yang berpotensi dan tidak dapat dipisahkan dari organisasi atau unit kerja. Gaya kepemimpinan merupakan perilaku pemimpin yang digunakan seseorang ketika ingin mempengaruhi orang lain. Menurut Robert House sebagaimana dikutip oleh Robbins (2007) mengungkapkan bahwa terdapat empat macam klasifikasi kepemimpinan Path Goal, yakni gaya kepemimpinan direktif, gaya kepemimpinan suportif, gaya kepemimpinan partisipatif, dan gaya kepemimpinan berorientasi pada tugas.

Bermacam-macam gaya kepemimpinan dapat digunakan oleh seorang pemimpin untuk mempengaruhi dan memotivasi bawahannya, sehingga dapat meningkatkan kinerja bawahannya dalam melakukan pekerjaan. Pimpinan perusahaan selain memperhatikan kinerja karyawannya, pimpinan perusahaan juga harus memperhatikan kesejahteraan karyawannya. Hal ini dapat diwujudkan melalui adanya komunikasi yang baik antara pimpinan dengan karyawan. Komunikasi yang baik antara pimpinan dengan karyawan dapat memberikan efek positif bagi kemajuan perusahaan yang dimana membuat perusahaan tersebut semakin berkembang dan mampu bekerja sama untuk memenuhi tuntutan lingkungan. Dengan menciptakan gaya kepemimpinan yang baik bagi suatu perusahaan maka akan menciptakan kinerja karyawan yang baik pula dan akan meningkatakan kepuasan kerja pada perusahaan itu sendiri. Berdasarkan uraian di atas, maka hipotesis ketiga yang diajukan adalah sebagai berikut:

$\mathrm{H}_{3}$ : Gaya kepemimpinan berpengaruh positif dan signifikan terhadap produktivitas kerja karyawan pada CV. Tenaga Inti dan CV. Bima Sakti.

Hasil penilaian kinerja karyawan pada umumnya berbeda-beda antara karyawan yang satu dengan yang lainnya. Hal tersebut tentu dipengaruhi oleh beberapa faktor, sehingga manajer perusahaan harus benar-benar mampu dalam mengidentifikasi dan memahami faktor-faktor tersebut yang kemudian dilanjutkan dengan tindakan penanganan yang efektif pula. Secara umum banyak sekali faktor-faktor yang dapat dan sering mempengaruhi kinerja karyawan, dan salah satu contohnya adalah faktor kepuasan kerja. Kepuasan kerja merupakan sesuatu hal yang diharapkan oleh setiap karyawan di perusahaan. Biasanya, karyawan yang merasa puas akan mengarah pada kondisi diri yang positif seperti merasa semangat dan giat dalam bekerja. Mengingat pentingnya kepuasan kerja karyawan, maka kepuasan kerja merupakan salah satu faktor yang perlu mendapat perhatian pimpinan perusahaan. Dalam kenyataannya banyak pimpinan perusahaan belum sepenuhnya menyadari pengaruh dan arti penting dari kepuasan kerja. Bahkan perusahaan masih menganggap sumber daya manusia sebagai biaya (cost) bagi perusahaan, sehingga pengelolaan SDM yang ada belum maksimal dilakukan. Berdasarkan uraian di atas, maka hipotesis keempat yang diajukan adalah sebagai berikut:

$\mathrm{H} 4$ : Kepuasan kerja berpengaruh positif dan signifikan terhadap produktivitas kerja karyawan pada CV. Tenaga Inti dan CV. Bima Sakti. 


\section{Metode}

Penelitian ini menggunakan pendekatan kuantitatif, dimana penelitian ini menggunakan instrumen dalam pengukurannya dan mengolahnya secara statistik dan berbentuk angkaangka. Penelitian ini dilakukan pada CV Tenaga Inti Sangsit dan CV. Bima Sakti. Populasi dalam penelitian ini adalah seluruh karyawan pada CV Tenaga Inti Sangsit dan CV. Bima Sakti sejumlah 80 orang. Metode pengambilan sampel yang digunakan dalam penelitian ini adalah metode sampel jenuh/total sampling, sehingga jumlah sampel sama dengan populasi yakni 80 responden. Data penelitian ini dikumpulkan dengan menggunakan kuesioner yang kemudian diolah dengan uji analisis regresi linear berganda dengan bantuan SPSS.

\section{Hasil dan Pembahasan}

Hasil pada penelitian ini meliputi hasil uji statistik deskriptif, uji kualitas data, uji asumsi klasik, dan uji hipotesis. Hasil uji statistik deskriptif pada penelitian ini disajikan pada tabel 1.

Tabel 1. Hasil Uji Statistik Deskriptif

\begin{tabular}{lccccc}
\hline & $N$ & Min & Max & Mean & Std. Deviation \\
\hline Partisipasi Anggaran & 80 & 29 & 40 & 34,05 & 2,981 \\
Teknologi Informasi & 80 & 29 & 40 & 32,76 & 2,935 \\
Gaya Kepemimpinan & 80 & 33 & 48 & 38,10 & 3,696 \\
Kepuasan Kerja & 80 & 30 & 40 & 33,23 & 3,765 \\
Produktivitas Kerja & 80 & 16 & 24 & 19,01 & 2,149 \\
Valid N (Listwise) & 80 & & & & \\
\hline
\end{tabular}

Pada tabel 1 dapat dilihat bahwa variabel partisipasi anggaran $\left(\mathrm{X}_{1}\right)$ mempunyai skor minimum 29, skor maksimum 40, skor rata-rata 34,05 dengan standar deviasi 2,981. Hal ini menunjukkan bahwa terjadi perbedaan nilai partisipasi anggaran terhadap nilai rata-rata sebesar 2,981. Variabel teknologi informasi $\left(X_{2}\right)$ mempunyai skor minimum 29, skor maksimum 40, skor rata-rata 32,76 dengan standar deviasi 2,935. Hal ini menunjukkan bahwa terjadi perbedaan nilai teknologi informasi terhadap nilai rata-rata sebesar 2,935.

Variabel gaya kepemimpinan $\left(X_{3}\right)$ mempunyai skor minimum 33, skor maksimum 48 , skor rata-rata 38,10 dengan standar deviasi 3,696. Hal ini menunjukkan bahwa terjadi perbedaan nilai gaya kepemimpinan terhadap nilai rata-rata sebesar 3,696 . Variabel kepuasan kerja $\left(X_{4}\right)$ mempunyai skor minimum 30 , skor maksimum 40 , skor rata-rata 33,23 dengan standar deviasi 3,765. Hal ini menunjukkan bahwa terjadi perbedaan nilai kepuasan kerja terhadap nilai rata-rata sebesar 3,765. Variabel produktivitas kerja (Y) mempunyai skor minimum 16, skor maksimum 24, skor rata-rata 19,01 dengan standar deviasi 2,149. Hal ini menunjukkan bahwa terjadi perbedaan nilai produktivitas kerja terhadap nilai rata-rata sebesar 2,149.

Uji yang dilakukan selanjutnya adalah uji kualitas data meliputi uji validitas dan uji reliabilitas. Uji validitas bertujuan untuk menguji seberapa baik instrumen penelitian mengukur konsep yang seharusnya diukur. Untuk menguji apakah instrumen yang digunakan nilai Pearson Corelation. Hasil pengujian pada penelitian ini menunjukkan bahwa semua instrumen memiliki nilai Pearson Correlation lebih besar daripada 0,3 dan nilai Sig. (2-tailed) korelasi untuk semua item lebih kecil daripada 0,05 sehingga dapat disimpulkan seluruh item pernyataan dinyatakan valid.

Setelah itu, dilakukan uji reliabilitas secara bersama-sama terhadap seluruh item pertanyaan dalam suatu kuesioner. Hasil pengujian menunjukkan bahwa variabel partisipasi anggaran mempunyai nilai Cronbach's Alpha sebesar 0,791. Variabel teknologi informasi mempunyai nilai Cronbach's Alpha sebesar 0,824. Variabel gaya kepemimpinan mempunyai nilai Cronbach's Alpha sebesar 0,904. Variabel kepuasan kerja mempunyai nilai Cronbach's Alpha sebesar 0,938. Variabel produktivitas kerja mempunyai nilai Cronbach's Alpha sebesar 0,880. Semua variabel mempunyai nilai Cronbach's Alpha lebih besar dari 0,60, sehingga dapat dinyatakan bahwa instrumen yang digunakan pada penelitian ini adalah reliabel. 
Setelah uji kualitas data terpenuhi, dilakukan uji asumsi klasik. Pada penelitian ini dilakukan 3 uji asumsi klasik yaitu uji normalitas, uji multikolinearitas dan uji heteroskedastisitas. Dalam uji normalitias ada dua cara untuk mendeteksi apakah residual berdistribusi normal atau tidak yakni menggunakan analisis grafik dan uji statistik. Dalam penelitian ini, alat uji yang digunakan adalah uji statistik dengan Kolmogorov-Smirnov Z. Nilai Kolmogorov-smirnov $Z$ yang digunakan adalah 0,05 . Jika profitabilitas $>0,05$, maka distribusi dari model regresi adalah normal, sedangkan jika profitabilitas $<0,05$, maka distribusi dari model regresi adalah tidak normal. Hasil pengujian yang dilakukan menunjukkan bahwa nilai Kolmogorov Smirnov sebesar 0,104 dengan nilai signifikansi sebesar 0,064 >0,05. Hal ini menunjukkan bahwa nilai residual berdistribusi secara normal dan dapat digunakan dalam penelitian (Ghozali, 2011).

Uji asumsi klasik yang kedua yaitu uji multikolinearitas. Pada uji multikolinearitas apabila nilai Variance Inflation Faktor (VIF) tidak lebih dari 10 dan nilai Tolerance tidak kurang dari 0,10 maka model dapat dikatakan terbebas dari multilkoliniaritas dan dapat digunakan dalam penelitian. Hasil pengujian multikolinearitas menunjukkan bahwa semua variabel independen mempunyai nilai VIF lebih kecil daripada 10 dan nilai tolerance lebih besar 0,10, sehingga dapat disimpulkan bahwa model bebas dari multikolinearitas.

Uji asumsi klasik yang selanjutnya dilakukan uji heteroskedastisitas. Uji heteroskedasitas dilakukan melalui uji Glejser. Jika probabilitas signifikan masing-masing variabel independen $>0,05$, maka dapat disimpulkan tidak terjadi heteroskedastisitas. Hasil uji heteroskedastisitas pada penelitian ini menunjukkan bahwa variabel partisipasi anggaran mempunyai nilai sig. sebesar 0,055, variabel teknologi informasi mempunyai nilai sig. 0,138, variabel gaya kepemimpinan mempunyai nilai sig. sebesar 0,200 , dan variabel kepuasan kerja mempunyai nilai sig. sebesar 0,477 . Semua variabel mempunyai probabilitas signifikansi $>0,05$, sehingga dapat disimpulkan model regresi tidak mengandung adanya heteroskedastisitas.

Setelah uji asumsi klasik terpenuhi selanjutnya dilakukan uji hipotesis. Hipotesis pada penelitian ini diuji dengan menggunakan model regresi berganda. Uji hipotesis yang pertama dilakukan adalah uji koefisien determinasi. Hasil uji koefisien determinasi disajikan pada tabel 2.

Tabel 2. Uji Koefisien Determinasi

\begin{tabular}{|l|c|c|c|c|}
\hline Model & $R$ & $R$ Square & Adjusted $R$ Square & Std. Error of the Estimate \\
\hline 1 & $0,967^{\text {a }}$ & 0,935 & 0,932 & 0,56062 \\
\hline
\end{tabular}

Pada tabel 2 dapat dilihat bahwa nilai Adjusted $R$ Square sebesar 0,932 yang menunjukkan bahwa variasi variabel partisipasi anggaran, teknologi informasi, gaya kepemimpinan, dan kepuasan kerja mampu menjelaskan 93,2\% variasi variabel produktivitas kerja. Sisanya sebesar $6,8 \%$ dipengaruhi oleh faktor lain di luar penelitian ini yang dapat mempengaruhi produktivitas kerja.

Tabel 3. Hasil Uji Statistik t

\begin{tabular}{lrrrrrr}
\hline & \multicolumn{2}{c}{$\begin{array}{c}\text { Unstandardized } \\
\text { Coefficients }\end{array}$} & $\begin{array}{c}\text { Standardized } \\
\text { Coefficients }\end{array}$ & & \\
\cline { 2 - 5 } & \multicolumn{1}{c}{$B$} & Std. Error & Beta & & \multicolumn{1}{c}{ Sig. } \\
\hline 1 (Constant) & 11,339 & 1,137 & & 1,179 & 0,024 \\
Partisipasi Anggaran & 0,015 & 0,026 & 0,021 & 2,580 & 0,046 \\
Teknologi Informasi & 0,048 & 0,025 & 0,066 & 2,897 & 0,036 \\
Gaya Kepemimpinan & 0,565 & 0,017 & 0,972 & 3,510 & 0,000 \\
Kepuasan Kerja & 0,103 & 0,017 & 0,006 & 2,200 & 0,028 \\
\hline
\end{tabular}

a. Variable: Produktivitas kerja Dependent 
Selanjutnya dilakukan uji statistik t yang menunjukkan seberapa besar pengaruh satu variabel independen secara individu dalam menjelaskan variansi variabel dependen. Hasil uji statistik t pada penelitian ini disajikan pada tabel 3. Pada tabel tersebut, dapat dilihat bahwa variabel partisipasi anggaran memiliki nilai signifikansi sebesar 0,046 $<0,05$, maka dapat dinyatakan bahwa variabel $X_{1}$ mempunyai kontribusi terhadap $Y$. Nilai t positif menunjukkan bahwa variabel $X_{1}$ mempunyai hubungan yang searah dengan $Y$. Jadi dapat disimpulkan bahwa $\mathbf{H}_{1}$ diterima yaitu partisipasi anggaran berpengaruh positif dan signifikan terhadap produktivitas kerja. Hasil penelitian ini sejalan dengan penelitian sebelumnya yang dilakukan oleh Mursyid (2011) yang menyatakan bahwa partisipasi anggaran berpengaruh signifikan terhadap kinerja manajerial.

Variabel teknologi informasi memiliki nilai signifikansi sebesar 0,036 $<0,05$, maka dapat dinyatakan bahwa variabel $\mathrm{X}_{2}$ mempunyai kontribusi terhadap $\mathrm{Y}$. Nilai $\mathrm{t}$ positif menunjukkan bahwa variabel $\mathrm{X}_{2}$ mempunyai hubungan yang searah dengan $\mathrm{Y}$. Jadi dapat disimpulkan bahwa $\mathbf{H}_{2}$ diterima yaitu teknologi informasi berpengaruh positif dan signifikan terhadap produktivitas kerja. Hasil penelitian ini sejalan dengan penelitian sebelumnya yang dilakukan oleh Rai Darmini dan Asmara Putra (2009) dan Bangun Kinarwanto (2008) yang membuktikan bahwa pemanfaatan teknologi informasi berpengaruh positif dan signifikan terhadap kinerja karyawan di perusahaan. Menurutnya dengan teknologi informasi individu di perusahaan dapat menghasilkan ouput dan kinerja yang semakin baik.

Variabel gaya kepemimpinan memiliki nilai signifikansi sebesar $0,000<0,05$, maka dapat dinyatakan bahwa variabel $\mathrm{X}_{3}$ mempunyai kontribusi terhadap $\mathrm{Y}$. Nilai $t$ positif menunjukkan bahwa variabel $X_{3}$ mempunyai hubungan yang searah dengan $Y$. Jadi dapat disimpulkan bahwa $\mathbf{H}_{3}$ diterima yaitu gaya kepemimpinan berpengaruh positif dan signifikan terhadap produktivitas kerja. Hasil penelitian ini sejalan dengan penelitian sebelumnya yang dilakukan oleh Susanta et.al. (2013) yang menyatakan bahwa kepemimpinan berpengaruh positif terhadap kinerja karyawan pada jasa konstruksi di Denpasar. Hasil penelitian Prasetyo (2018) juga menyatakan bahwa gaya kepemimpinan otokratis berpengaruh signifikan terhadap kinerja karyawan pada PT. Sahbana Citra Mandiri di Tenggarong.

Variabel kepuasan kerja memiliki nilai signifikansi sebesar 0,028 $<0,05$, maka dapat dinyatakan bahwa variabel $\mathrm{X}_{4}$ mempunyai kontribusi terhadap $\mathrm{Y}$. Nilai t positif menunjukkan bahwa variabel $\mathrm{X}_{4}$ mempunyai hubungan yang searah dengan $\mathrm{Y}$. Jadi dapat disimpulkan bahwa $\mathbf{H}_{\mathbf{4}}$ diterima yaitu kepuasan kerja berpengaruh positif dan signifikan terhadap produktivitas kerja. Hasil penelitian ini sejalan dengan penelitian sebelumnya yang dilakukan oleh Pangaribuan (2014) tentang pengaruh kepuasan kerja karyawan terhadap produktivitas karyawan pada PT. Dua Titik Advertama Bandung menyatakan bahwa ada pengaruh signifikan anatara kepuasan kerja karyawan terhadap produktifitas karayawan dimana apabila tingkat kepuasan kerja tinggi maka tingkat produktivitas makin meningkat. Hasil penelitian yang dilakukan oleh Wirawan (2012) juga menunjukkan bahwa terdapat pengaruh positif dan signifikan antara kepuasan kerja terhadap produktivitas kerja karyawan PT CRESTEC Indonesia.

\section{Simpulan dan Saran}

Berdasarkan hasil penelitian maka peneliti menyimpulkan, bahwa partisipasi anggaran teknologi informasi, gaya kepemimpinan dan kepuasan kerja berpengaruh positif dan signifikan terhadap produktivitas kerja karyawan CV Tenaga Inti Sangsit dan CV. Bima Sakti. Selain itu, adanya partisipasi dalam penyusunan anggaran dan pimpinan memiliki gaya kepemimpinan yang partisipasif maka tentu saja akan meningkatkan produktivitas kerja karyawan CV Tenaga Inti Sangsit dan CV. Bima Sakti. Begitu juga, ketika perusahaan menerapkan teknologi informasi, maka peran pimpinan dalam manajerial sangat diperlukan sehingga karyawan yang diharapkan dapat meningkatkan kepuasan kerja dapat terelaiasai. Dengan adanya hal tersebut, maka CV Tenaga Inti Sangsit dan CV. Bima Sakti dapat meningkatkan produktivitas kerja karyawannya.

Adapun saran yang dapat disampaikan bagi pimpinan pada CV Tenaga Inti Sangsit dan CV. Bima Sakti diharapkan dapat ikut berpartisipasi dalam penyusunan anggaran perusahaan dan melakukan review terhadap pembuatan anggaran sehingga anggaran yang 
dirancang akan sesuai dengan perencanaan perusahaan kedepannya. Pimpinan juga diharapkan menerapkan kepemimpinan yang partisipasif dengan menggunakan kemampuan untuk membina kerjasama dan hubungan baik dalam mendelegasi tugas dan wewenang secara lebih efektif.

Bagi karyawan CV Tenaga Inti Sangsit dan CV. Bima Sakti diharapkan dapat mengoptimalkan produktivitas kerja dengan meningkatkan kepuasan kerja dalam hal kepuasan terhadap situasi kerja, hubungan sosial dalam bekerja, dan kepuasan terhadap imbalan kerja. Selain itu, karyawan juga diharapkan dapat memanfaatkan teknologi informasi yang disediakan oleh perusahaan dalam upaya untuk meningkatkan kualitas dan produktivitas kerja yang lebih efektif dan efisien.

Selain itu, peneliti selanjutnya disarankan dapat memperluas penelitian dengan menambah jumlah sampel dengan dasar bahwa sampel penelitian ini masih kurang hanya di dua perusahaan saja, tetapi dibutuhkan sampel di lebih banyak perusahaan, sehingga hasil penelitian akan lebih baik. Selain itu, peneliti selanjutnya diharapkan dapat mengembangkan penelitian ini secara lebih lanjut dan mempertimbangkan variabel lain yang belum diuji dalam penelitian ini dikarenakan Adjusted $R$ Square bernilai 93,2\% dan sisanya sebesar 6,8\% dipengaruhi oleh variabel lain di luar penelitian ini yang dapat mempengaruhi produktivitas kerja, seperti tingkat pendidikan karyawan, tingkat kompensasi, dan lain sebagainya.

\section{Daftar Pustaka}

Ervianto. 2004. Teori Aplikasi Manajemen Proyek Konstruksi. Yogyakarta: Salemba Empat.

Gregory, R.J. 2011. Psychological Testing: History, Priciples, and Application (Sixth Edition) Boston: Pearson Education, Inc.

Koyan I W. 2012. Statistik Pendidikan Teknik Analisis Data Kuantitatif. Singaraja: Universitas Pendidikan Ganesha Press.

Mathis, L Robert dan John H. Jackson. 2006. Human Resource Management (Manajemen Sumber Daya Manusia). Edisi ke-10. Jakarta: Salemba Empat).

Megawati, N. L. A. 2018. Pengaruh Implementasi Prinsip-Prinsip Good Corporate Governance (GCG), Budaya Organisasi dan Gaya Kepemimpinan Terhadap Kinerja Hotel Berbintang di Kabupaten Buleleng. Skripsi. Universitas Pendidikan Ganesha.

Sedarmayanti. 2009. Sumber Daya Manusia dan Produktivitas Kerja. Cetakan Ketiga. Bandung: CV. Mandar Maju.

Suharsaputra, Uhar. 2014. Metode Penelitian Kuantitatif, Kualitatif dan Tindakan, Edisi Kedua. Bandung: PT Refika Aditama.

Sumarno, E., 2013. Pengaruh Kompensasi dan Motivasi Terhadap Produktivitas Kerja Melalui Kepuasan Kerja Sebagai Variabel Intervening. Jurnal IImu Administrasi Bisnis.

Sunjoyo. 2013. Aplikasi Spss untuk Smart Riset (Program IBM Spss 21.0). Bandung: Alfabeta. 